\title{
50 years have passed, current state, studies and safety assessment of hanging roof above the main sport and entertainment hall in Katowice
}

\author{
Rafał Szydłowski ${ }^{1, *}$ and Barbara Labuzek $^{2}$ \\ ${ }^{1,2}$ Cracow University of Technology, Warszawska 24 Street, Cracow 31-155 \\ ${ }^{1,2}$ TCE Structural Design \& Consulting, Domikanow 14 Street, Cracow 31-409
}

\begin{abstract}
The article presents a brief description of the 50-year-old history of the Katowice "Spodek", and cites the selected facts about the object, beginning at the stage of design and realization to exploitation. The structure of the building has been described with great emphasis on the construction of the covering suspended on cable girders in combination with original architecture was an extremely bold constructional solution of those times. The main part of this work includes results of research from force measurements conducted in tendons realized in the present year, that is in 2019 , together with their analysis with reference to archival results from research conducted in the years $1971,1978,1985,1990$ or 2006. Particular attention is drawn to the fact, that despite the passage of time, the elaborated method for measurements and measurement devices used for research has not changed across the years and still allows to obtain the relevant picture of the construction's performance. The obtained results have shown that the assumptions adopted for the then innovative solutions were received correctly, and the renovation works in the scope of roof covering significantly disburdened the construction, allowing a considerable safety reserve despite its over half-century exploitation.
\end{abstract}

\section{Introduction}

In 1959, a competition for the project of a complex of buildings at the Provincial Sports and Entertainment Arena was announced. The first prize in the competition was awarded to the project of the Bureau of Studies and Projects of Typical Industrial Buildings in Warsaw, whose architecture, freely inspired by the Supersam market roof at Puławska 2 Street in Warsaw, was developed by Maciej Gintowt and Maciej Krasiński, while the construction was created by Wacław Zalewski. The shape of a flying saucer was proposed as the body of the sports arena; its cubature of $250,000 \mathrm{~m}^{3}$ constitutes almost $70 \%$ of the volume of the entire complex. The winning design did not have its counterpart in world construction.

Initially, the designed arena was planned to be located in the suburbs of Katowice, but in the light of its splendor, it was decided to change its location to the very center of Katowice,

\footnotetext{
${ }^{*}$ Corresponding author: rszydlowski@pk.edu.pl
} 
at the intersection of today's Korfanty and Rozdzieński avenues. The model of the winning design of the complex of buildings is shown in Figure 1.

Construction of the object began in 1964 and took five years. The arena was officially opened on May 8, 1971; due to the innovativeness of the construction project, it was preceded by an attempt to load the roof, which was done by inviting 4,000 soldiers who weighted down the structure dynamically by jumping and stomping and confirmed the correct assumptions adopted at the design stage. The arena has fulfilled many functions over the years. Among other things, it was the meeting place for the Polish youth with Fidel Castro, numerous concerts of famous Polish and world stars, sports events, and cinema screenings. The first event that made the UFO-shaped object the most famous was the Fiat 126p show during the "Great Car Show" in 1972.

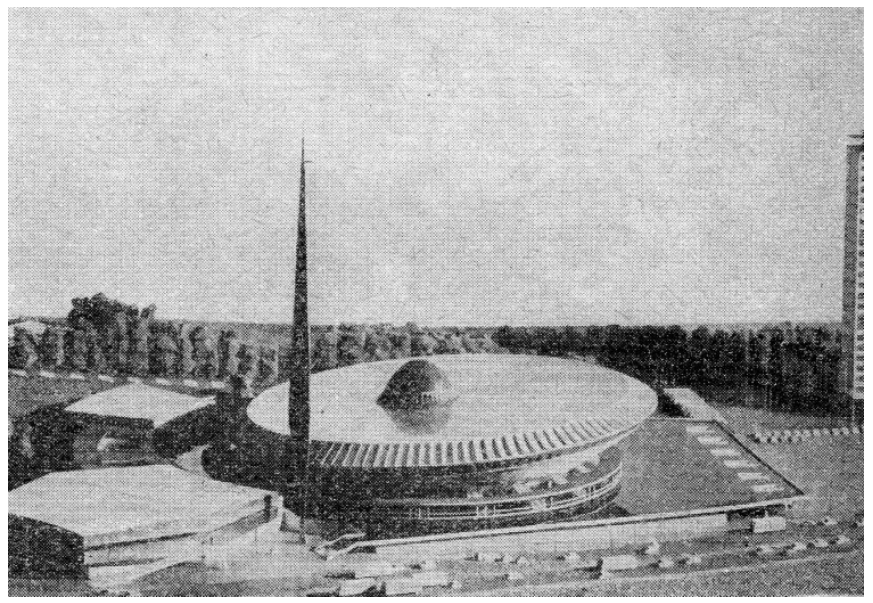

Fig. 1. Mock-up of the winning concept of Sports and Entertainment Arena "Spodek" [1].

\section{Design process}

The change in the location of the designed arena significantly affected the project. The greatest difficulty faced by the project team was the location. The chosen area was greatly affected by mining damage which occurred after the already completed coal exploitation and damage from the exploitation at that time. Soil turned out to be an additional challenge; it was very diverse and unevenly bedded. The above-mentioned difficulties contributed to the evolution of the project and ultimately, its fourth concept was implemented. The diagram of the completed structure is shown in Figure 2, and the exact course of the design stages is described in [1]. In the final version of the project, the saucer-shaped structure was based on a prestressed foundation ring (item 7), supported by inclined columns consisting of two parts: scissorlifts columns (item 11) and lower rocker (item 13), connected by an intermediate ring (item 12) on ground level. 


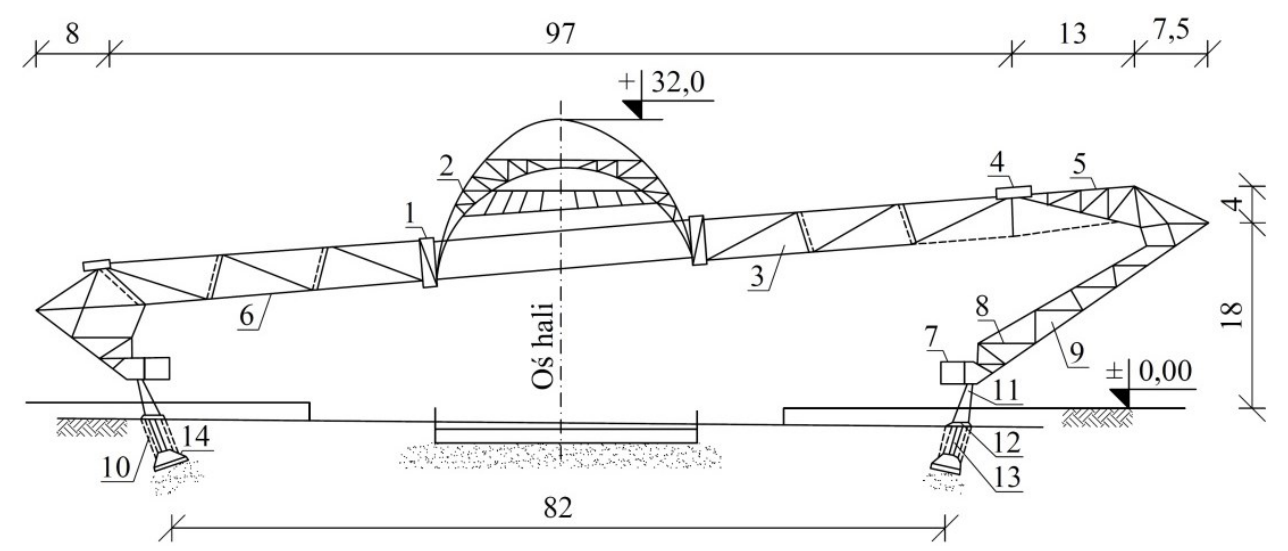

Fig. 2. Structural scheme of Sports and Entertainment Arena "Spodek": 1-steel inner ring , 2-dome, 3-technical storey, 4-steel outer ring, 5-truss cantilever columns, 6-cable-strut girder, 7-prestressed foundation ring, 8-reinforced concrete casing ring, 9-steel ribs, 10-rockers housing, 11- scissorlifts columns, 12-intermediate ring, 13- rockers columns,14-foundation foots [1]

\section{Construction of the suspended roof}

The arena's roof structure, shown in Figure 2, constitutes a steel dome, and the former covering in the form of layered asbestos cement slabs with a Styrofoam core is based on 120 cable-strut girders. The dome (Figure 2 - item 2) with a diameter of $32 \mathrm{~m}$ and a height of $16 \mathrm{~m}$ is constructed of 40 lattice longitudinal ribs and lattice grids, which are stituated on a circular stiffening ring (item 1) that absorbs tensile forces from cable girders (item 6). The essential elements of the roof structure - cable-rots girders, were radially spread between the inner stiffening ring (item 1) and the outer ring (item 4). The inner ring was built from the lower and upper steel trough, grated in both side planes (Fig. 3). The outer ring has a box cross section and is based on truss cantilever columns (item 5).

A cable girder with a span of $36.0 \mathrm{~m}$ (Fig. 3) was designed in the form of a flat truss, in which the bottom chords, top chords and diagonals are made of cables, while the geometry of the element is provided by two steel webs and shock absorbing pillars. Because the truss is formed in this way, the upper zone forms the roof plane, and the lower zone forms the ceiling of the technical floor, on which ventilation, electrical and mechanical technological devices are placed. The cable girder consists of 10 load-bearing cables and 2 stiffening cables, with a total of $118 \phi 5 \mathrm{~mm}$ strands. The girder diagram with the designation of cable functions and their cross-sections is shown in Figure 3. Load-bearing cables were formed from $18 \phi 5 \mathrm{~mm}$ strands, while stiffening with $9 \phi 5 \mathrm{~mm}$ ones.

The complex forms of the load-bearing tendon and the geometry and inclination of girders have influenced the difficulties in anchoring the cables, which were finally developed by the Institute of Building Materials and Structures of the Cracow University of Technology [3]. The technology of mass production of anchorage system was researched, and elaborated at the Cracow University of Technology. There were 4,800 anchorages and 48,000 headers made. The anchorage was designed from tool steel 55 (now C55), as a two-piece composed of a nut and a bolt with an M38 thread (Fig. 4a). Anchorage tests were carried out at the preparatory phase, during which cables were strained to test breakage and additional fatigue testing was performed. In the anchorage zone, even $18 \phi 5$ cable is divided into two strands, which are fixed in anchorages in the $9 \phi 5$ system. In each girder there are 20 passive anchors and 20 active anchors, mounted in the dome ring and in the steel outer ring box, respectively. 
Active anchors were designed to allow initial tension, measurement and adjustment of forces in the cables at various stages of assembly of the arena covering.

18 Strand cables are designed in the form of a bundle of strands arranged six in three rows. Figure 4a shows the structure of a $18 \phi 5 \mathrm{~mm}$ cable. Bundles of cables running in the upper and lower zones and diagonals are covered with coated steel sheet, creating tight gutters with a rectangular section (fig. 3). To secure steel cables, the gutters were filled with bituminous mix. Passive anchors were secured in an analogous manner. The construction of the anchorage head was filled with resin concrete. Eight of 120 heads are secured in such a way as to enable measurements of forces in cables in individual girders. Fig. 5 shows a diagram of the arrangement of girders with the designation of those where control measurements were made over the years of exploitation.

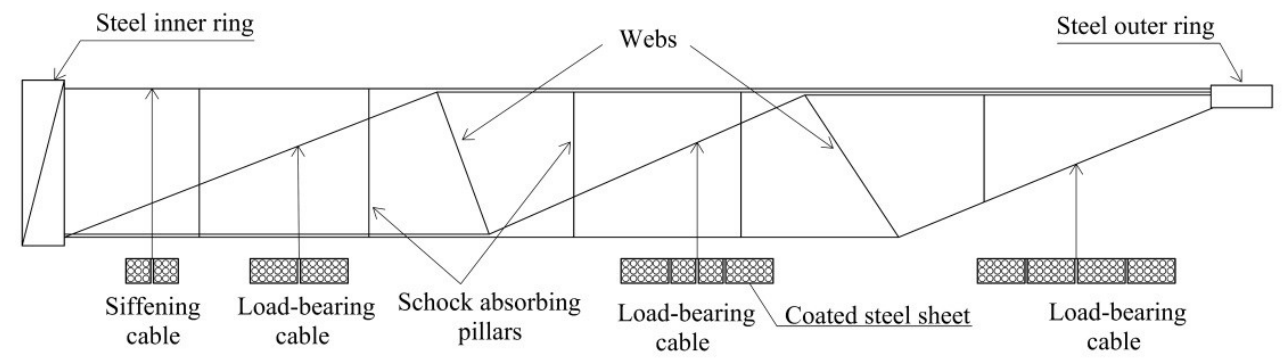

Fig. 3. Scheme of cable-strut girder with cross-section of each cable [3].

a)

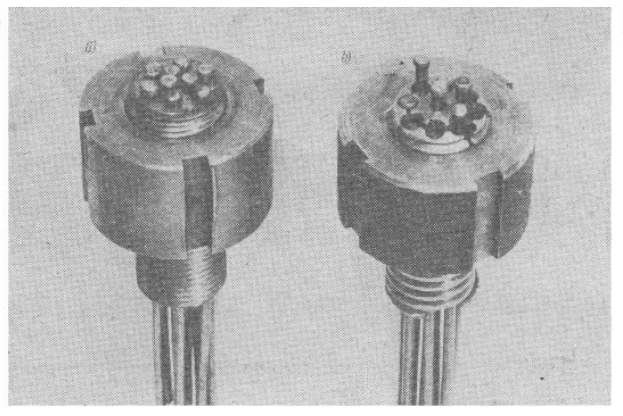

b)

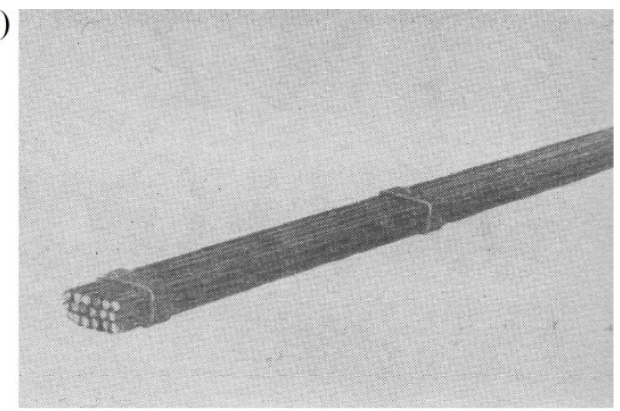

Fig. 4. The structure of bipartite anchorage (a) and cable $18 \phi 5$ (b) [3].

\section{Implementation and first research}

Roof girders were manufactured in prefabrication technology. The place of prefabrication was the construction site, where stands for particular stages of work were assigned. The first stage consisted in straightening the strings and forming cables. Straightened cables were cut to the appropriate length and pulled to improve the force parameters. The last stage of prefabrication was formation of girders, which were then assembled into the construction. After the assembly of all 120 girders, cables in three girders were stretched simultaneously and spaced every $120^{\circ}$. Stiffening cables of $9 \phi 5 \mathrm{~mm}$ were tightened as the first to a force of $7.5 \mathrm{~T}$, and this was followed by load-bearing cables.

Assembly of the roof structure was done in multiple stages, which resulted in numerous changes of forces in the girder cables. Due to performance reasons and assembly conditions, the outer ring pipe supports were dismounted after the execution of 99 girders. Especially in the second case, this had a significant impact on the values of forces in the already mounted girders. It was necessary to measure the force increments in order to be able to introduce a correction of forces in the girders mounted at a later time. 
Measurements of the anchoring force in selected cable girders were carried out in 7 subsequent load phases. In order to obtain a homogenous roofing, a uniform force equal to $7.5 \mathrm{~T}$ was obtained in the girder's stiffening cables. For this purpose, after installing all 120 girders, the force was measured and adjusted to this value. Figure 5a demonstrates the results of measurements. The fractional line represents the actual force recorded in the stiffening cables after stressing all 120 girders, before adjusting the forces. After the adjustment, the force value was tested at random, showing only a slight deviation from the designed value of $7.5 \mathrm{~T}$.

Figure $5 \mathrm{~b}$ demonstrates the change of forces in load-bearing cables at various stages of construction. Phase I stands for the construction of 66 girders before disassembly of pipe supports of the outer ring, and phase II after disassembly of the supports. Phase III consists in the completion of assembly of 99 girders before, and phase IV after placing the dome. Phase V involves the execution of all 120 girders and phase VII the application of all additional strains (corrosion protection, roofing, load from technical tier). The final value of forces in cables was from 55 to 72 tons.
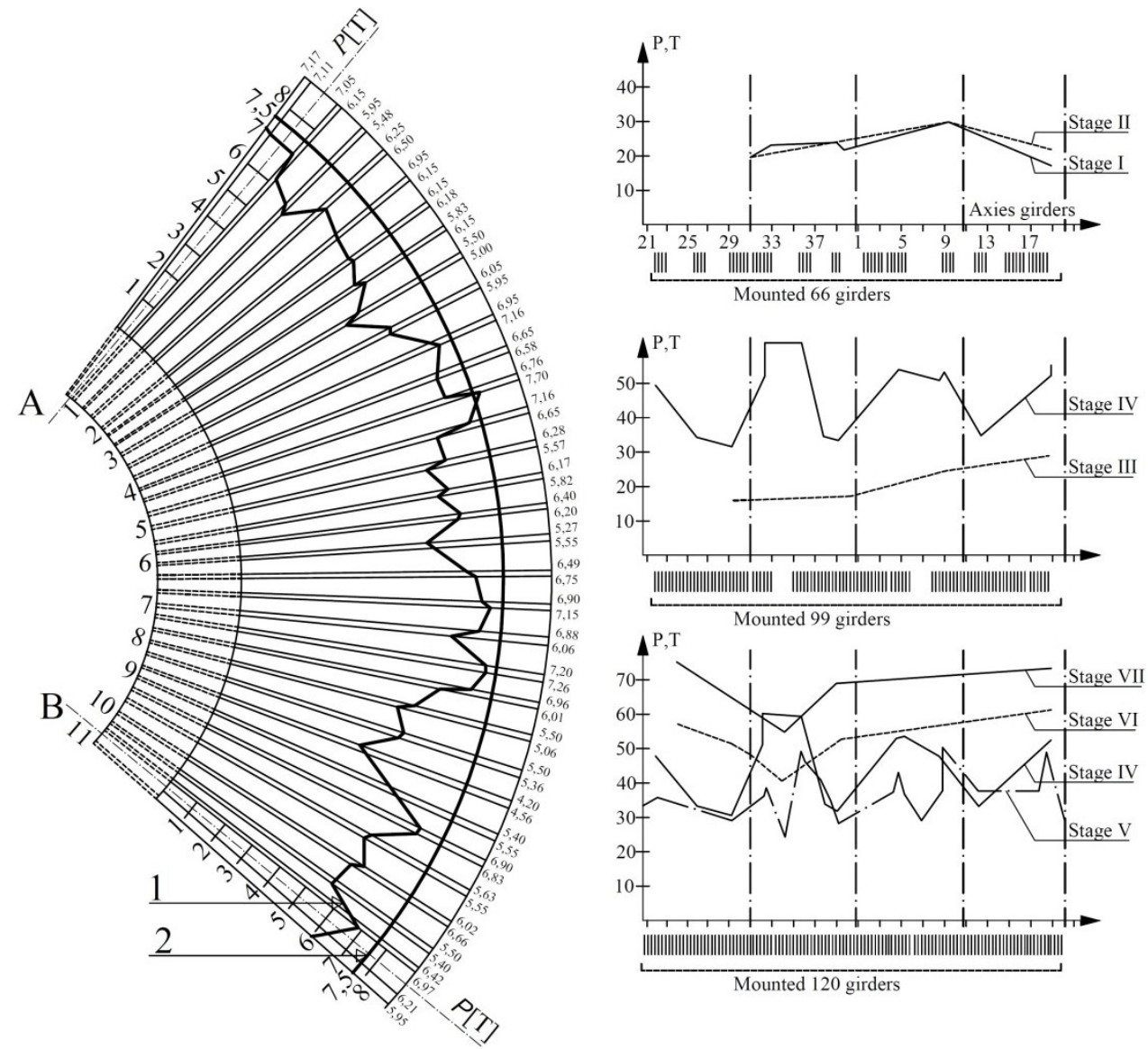

Fig. 5. Results of prestressing forces into stiffening cables after mount girders (a) (1- before regulation, 2 - designed value) and in load-bearing cables in each stages of roof execution (b) (description of stages in the text) [3]. 


\section{Periodic testing of forces in load-bearing cables}

The anchoring blocks of seven girders were not encapsulated and were protected against corrosion in a way that allowed control of forces in the load-bearing cables. The location of these girders is shown in Figure 6. Control measurement of forces was made in 1978, 1985, 1990, 2006 [4] and in 2019 [5]. Each time, measurement of force in girders' active anchors was made using a set, which was constructed and used to adjust forces during construction of the object (Fig. 7a). The set consists of a ring dynamometer (item 6 - fig. 8), a tensioning screw (4) with a tensioning nut (8) based on the thrust table (5) via a slide bearing (7). Measurement of force consists in pulling away the anchorage (1) with the tension bolt (4) by tightening the nut (8). Between the anchorage and the tensioning screw, there is a gauge (6) whose deformation constitutes a measure of the force in the system. The actual force in the tendon is the value measured using the dynamometer upon free movement of the nut (3).

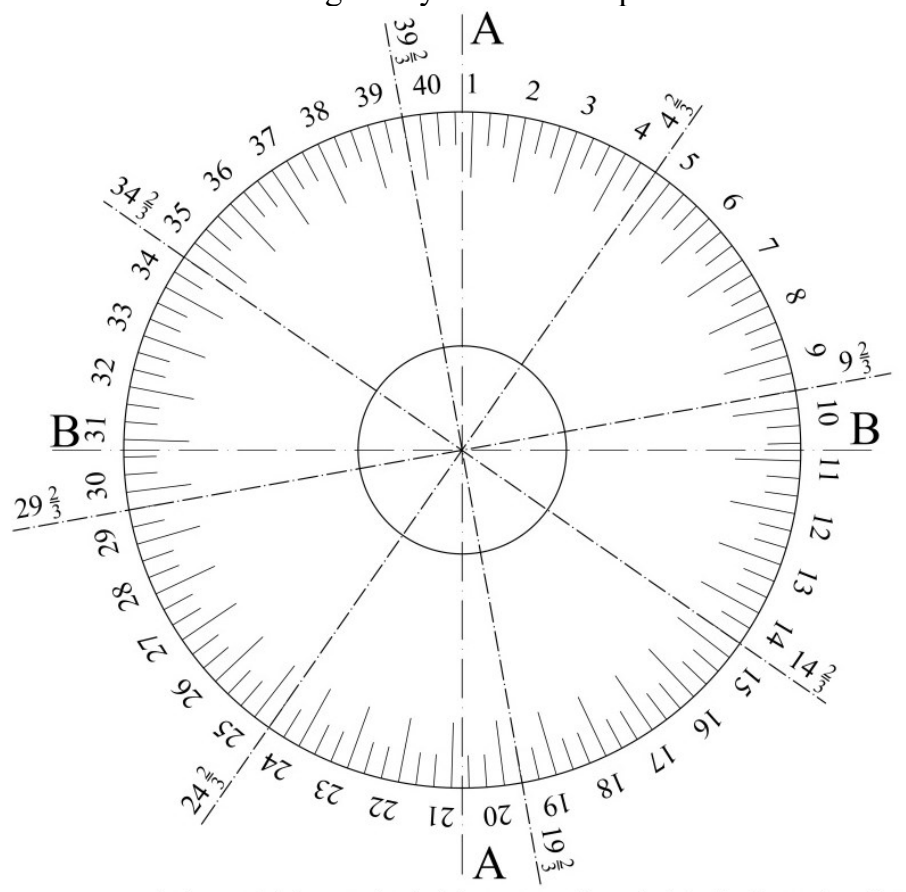

-._-_._- girders, which are adapted to carry out control test of prestressing force

Fig. 6. Location of girders adopted to carry out control of prestressing force in load-bearing cables.

a)

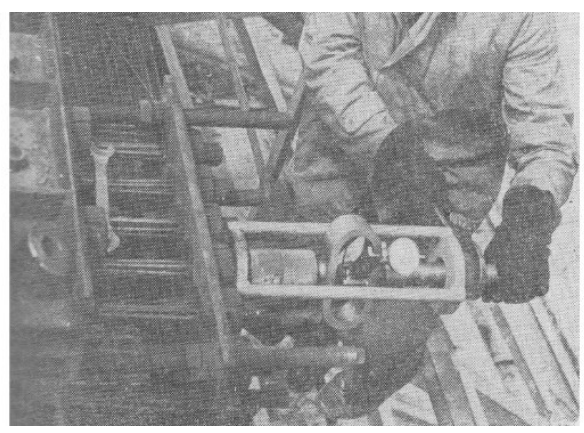

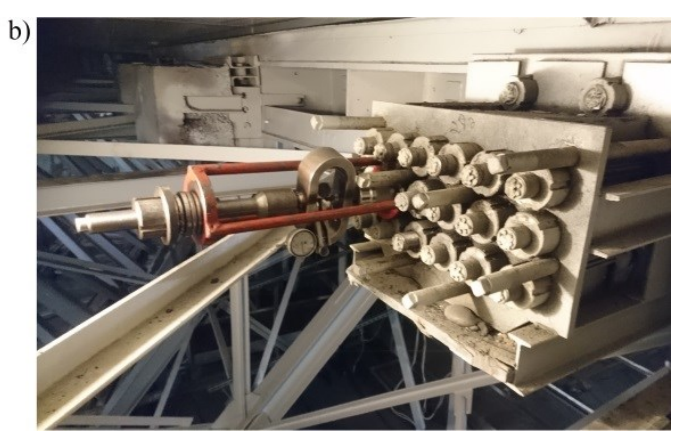

Fig. 7. The view of measurement equipment used to measure and control prestressing force in cables: a) during roof execution [3], b) during control measurements in 2018 [5]. 
a)

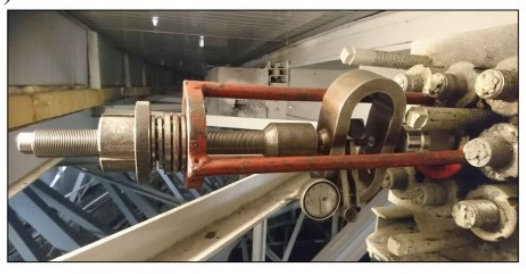

b) 2

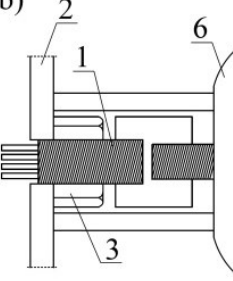

Measurement base $L$

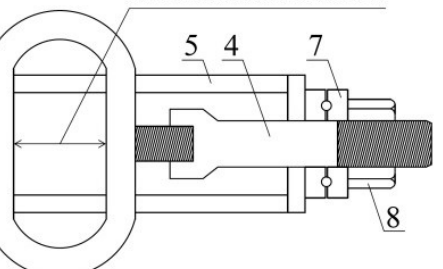

Fig. 8. The view (a) and structure (b) of equipment to control prestressing force: 1 - anchor bolt, 2 - resistance steel plate, 3 -anchor nut, 4 - tensioning screw, 5 - thrust table, 6 - ring dynamometer, 7 - slide bearing, 8 - tightening nut.

\section{Measurement results and assessment of roof safety}

Tables 1 and 2 demonstrate the results of measurements of forces in supporting cables of two of the five girders measured in 2019. The values of forces in individual $9 \phi 5$ bundles range from 29.1 to $48.5 \mathrm{kN}$ for girder $42 / 3$ and 28.0 to $48.4 \mathrm{kN}$ for girder $392 / 3$. The mean values of forces in the bundle are respectively 39.1 and $40.1 \mathrm{kN}$ and the average stresses in prestressing steel 221 and $226 \mathrm{MPa}$. The value of total force in cables, determined as the average force in the bundle multiplied by the number of bundles (measurement of force in two bundles of $42 / 3$ girder was impossible due to collision of the measurement set with roof concentrations) is 703 and $721 \mathrm{kN}$. The values of forces obtained are worth comparing with the values measured after completing the roof assembly, which varied from 55 to 72 tons (Figure 5.b - phase VII). The forces currently measured do not go beyond the range of forces registered in cables at that time.

Figure 9 shows a graphical demonstration of the change in forces in the tested girders in individual measurements conducted from 1971 to 2019 . The average values of measured forces in particular years are: $669 \mathrm{kN}$ in $1971,691 \mathrm{kN}$ in $1977,674 \mathrm{kN}$ in $1985,695 \mathrm{kN}$ in 1990 , $742 \mathrm{kN}$ in 2006 and $682 \mathrm{kN}$ in 2019 . It can be noted that up to 2006, the average force value grew systematically and the value of growth was $10.9 \%$. The largest increase of $6.8 \%$ occurred between 1990 and 2006. However, recent measurements conducted in 2019.

Table 1. The results of force measurement in girders $42 / 3$.

\begin{tabular}{|c|c|c|c|c|c|c|}
\hline Anchorage & $\mathbf{1} / \mathbf{A}$ & 1/B & $1 / \mathrm{C}$ & 1/D & $1 / E$ & $1 / F$ \\
\hline$\Delta L_{i}, \mathrm{~mm}$ & 2.96 & 2.62 & 2.21 & 3.03 & 2.82 & 3.37 \\
\hline$N_{i}, \mathrm{kN}$ & 39.0 & 34.5 & 29.1 & 40.0 & 37.2 & 44.4 \\
\hline$\sigma_{i}, \mathrm{MPa}$ & 220 & 195 & 164 & 226 & 210 & 251 \\
\hline Anchorage & $2 / \mathrm{A}$ & $2 / B$ & $2 / \mathrm{C}$ & 2/D & $2 / E$ & $2 / F$ \\
\hline$\Delta L_{i}, \mathrm{~mm}$ & 3.41 & 2.82 & 2.58 & 2.99 & 2.38 & 3.68 \\
\hline$N_{i}, \mathrm{kN}$ & 45.0 & 37.2 & 34.0 & 39.4 & 31.4 & 48.5 \\
\hline$\sigma_{i}, \mathrm{MPa}$ & 254 & 210 & 192 & 223 & 177 & 274 \\
\hline Anchorage & $3 / \mathrm{A}$ & 3/B & $3 / \mathrm{C}$ & 3/D & $3 / E$ & $3 / \mathbf{F}$ \\
\hline$\Delta L_{i}, \mathrm{~mm}$ & - & - & 2.85 & 2.74 & 3.52 & 3.39 \\
\hline$N_{i}, \mathrm{kN}$ & - & - & 37.6 & 36.1 & 46.4 & 44.7 \\
\hline$\sigma_{i}, \mathrm{MPa}$ & - & - & 212 & 204 & 262 & 253 \\
\hline $\begin{array}{l}\text { Total force at } \\
\text { anchorage block: }\end{array}$ & \multicolumn{2}{|c|}{$N=703 k N$} & \multicolumn{2}{|c|}{$\begin{array}{l}\text { Average steel } \\
\text { stress: }\end{array}$} & \multicolumn{2}{|c|}{$\sigma=220 \mathrm{MPa}$} \\
\hline
\end{tabular}


Table 2. The results of force measurement in girders $392 / 3$.

\begin{tabular}{|c|c|c|c|c|c|c|}
\hline Anchorage & $1 / A$ & $1 / B$ & $1 / \mathrm{C}$ & 1/D & $1 / E$ & $1 / \mathbf{F}$ \\
\hline$\Delta L_{i}, \mathrm{~mm}$ & 2.74 & 3.54 & 2.96 & 2.70 & 3.13 & 3.00 \\
\hline$N_{i}, \mathrm{kN}$ & 36.1 & 46.7 & 39 & 35.6 & 41.3 & 39.6 \\
\hline$\sigma_{i}, \mathrm{MPa}$ & 204 & 264 & 220 & 201 & 233 & 224 \\
\hline Anchorage & $2 / \mathrm{A}$ & $2 / B$ & $2 / \mathrm{C}$ & 2/D & $2 / E$ & $2 / \mathrm{F}$ \\
\hline$\Delta L_{i}, \mathrm{~mm}$ & 3.31 & 2.66 & 2.87 & 2.98 & 3.03 & 3.40 \\
\hline$N_{i}, \mathrm{kN}$ & 43.6 & 35.1 & 37.8 & 39.3 & 40.0 & 44.8 \\
\hline$\sigma_{i}, \mathrm{MPa}$ & 246 & 198 & 214 & 222 & 226 & 253 \\
\hline Anchorage & 3/A & 3/B & $3 / \mathrm{C}$ & 3/D & $3 / E$ & $3 / \mathbf{F}$ \\
\hline$\Delta L_{i}, \mathrm{~mm}$ & 3.52 & 3.67 & 2.81 & 2.80 & 2.12 & 3.42 \\
\hline$N_{i}, \mathrm{kN}$ & 46.4 & 48.4 & 37.1 & 36.9 & 28.0 & 45.1 \\
\hline$\sigma_{i}, \mathrm{MPa}$ & 262 & 273 & 210 & 208 & 158 & 255 \\
\hline $\begin{array}{l}\text { Total force at } \\
\text { anchorage block: }\end{array}$ & \multicolumn{2}{|c|}{$N=721 \mathrm{kN}$} & \multicolumn{2}{|c|}{$\begin{array}{l}\text { Average steel } \\
\text { stress: }\end{array}$} & \multicolumn{2}{|c|}{$\sigma=226 \mathrm{MPa}$} \\
\hline
\end{tabular}

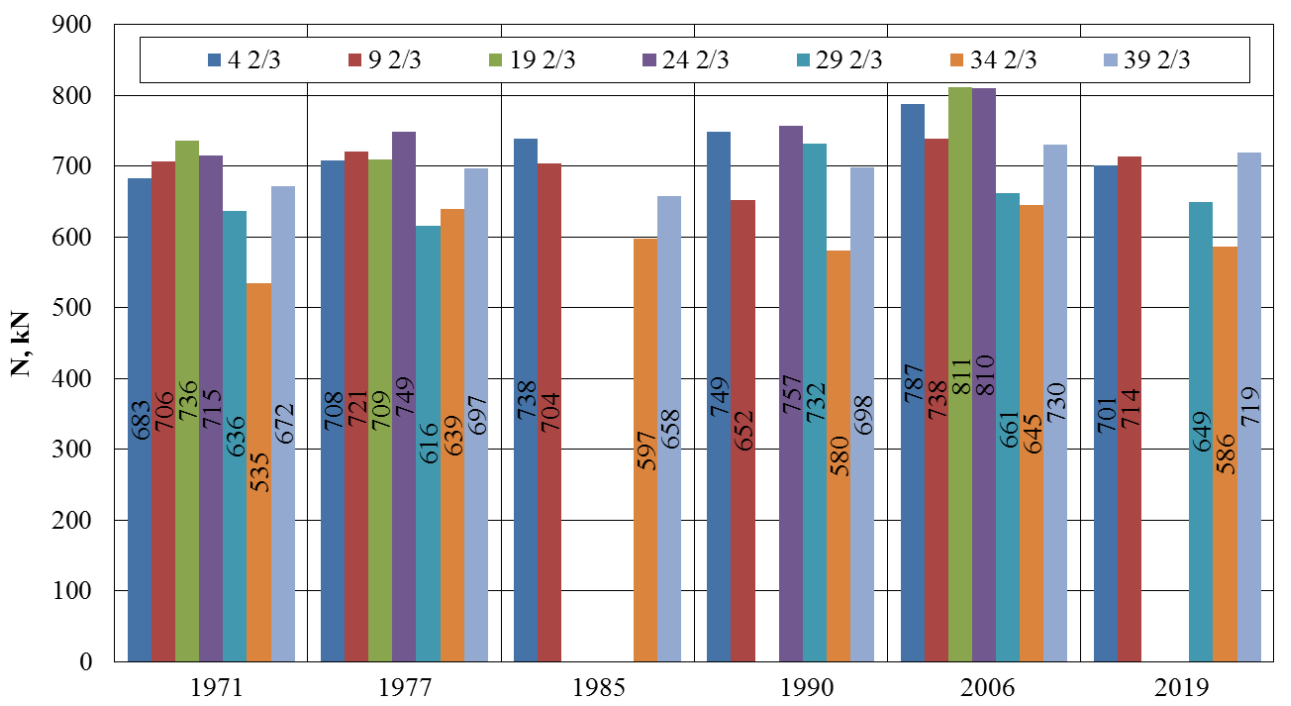

Fig. 9. Change of prestressing force in girders in 1971, 1977, 1985, 1990, 2006 and 2019.

showed a significant decrease in the average force in relation to the previously recorded value. The decrease was $8.1 \%$. The systematic increase of forces is easily explained by the systematically increasing roof load caused by continuous increase of equipment mounted on the technical ceiling. Thorough renovation of the roof was carried out between 2006 and 2019. Primary roof coverings made of layered asbestos cement panels have been changed to a much lighter cover in the form of modern sandwich panels. Moreover, according to the report of a user, a considerable amount of equipment installed on the technical ceiling has been dismantled. These treatments caused straining of the roof and a decrease in the average forces in the measured load-bearing cables by $8.1 \%$.

Analyzing the values of forces in cables obtained in the course of measurements, it was concluded that the average tensions in steel are $226 \mathrm{MPa}$ and the maximum tensions are $274 \mathrm{MPa}$ (girder 39 2/3). Sources do not indicate the resistance of steel, but steel commonly used to stress the structure displayed a maximum force of 1470MPa. Before assembly of all 
girders, all the cables, for the purpose of their testing, were prestressed for 10 minutes at a stress of $950 \mathrm{MPa}$ [3]. These stresses were twice as high as the maximum calculated for the full roof load. Taking into account the currently measured stress values, it can be stated that currently, the roof construction works at a high safety factor; without taking into account the snow load, it amounts to 4.2 in relation to the cable force tested experimentally before roof assembly and 6.5 in relation to steel's theoretical breaking force.

\section{Conclusions}

The complicated and unique roof construction of the "Spodek" sports and entertainment arena in Katowice, uncertainty of the construction authors $(4,000$ soldiers were engaged in testing the finished roof) as to the solutions used and an innovative stressing system developed specifically for the needs of this object, created the need to conduct periodic measurements of forces in the cables of roof girders. The measurements carried out from 1971 to 2019 showed that after almost 50 years of exploitation, the design assumptions regarding the efforts of the main load-bearing cables of the roof girders are fully met. A positive aspect was roof renovation performed at the end of the last decade, which disburdened the roof (decrease of average force in cables by $8.1 \%$ compared to previous measurements). At the time of the last measurements in January-February 2019, the measured girders worked with a safety factor equal to 4.2 in relation to the cable force tested experimentally before roof assembly and 6.5 in relation to steel's theoretical breaking force.

\section{References}

1. A. Żórawski, Ewolucja projektu konstrukcyjnego Hali Widowiskowo-Sportowej w Katowicach, Inżynieria i Budownictwo, 10, pp. 381-386 (1969) [in Polish]

2. Z. Gaszewsk, A. Żórwaski, Montaż stalowej kopuły dachowej o średnicy $32 \mathrm{~m}$, Inżynieria i Budownictwo, 11, pp. 413-417 (1970) [in Polish]

3. W. Detko, K. Dyduch, S. Libura, Zagadnienia technologiczne przy realizacji dachu wiszącego nad halą główną WHWS w Katowicach, Inżynieria i Budownictwo, 7, pp. 239-244 (1972) [in Polish]

4. R. Sieńko, R. Szydłowski, Odpowiedź przekrycia dachowego o konstrukcji cięgnowej na oddziaływanie w postaci fali akustycznej, Przegląd Budowlany, 5, pp. 41-44 (2013) [in Polish]

5. R. Sieńko, R. Szydłowski, Badania zmian sił w cięgnach przekrycia dachowego pod wpływem oddziaływania w postaci fali akustycznej, Czasopismo Techniczne, 4-B, pp. 183-191 (2012) [in Polish] 